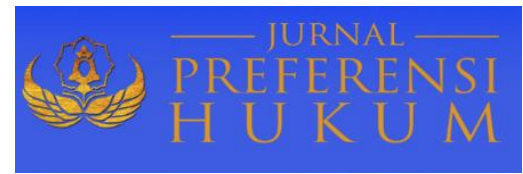

Jurnal Preferensi Hukum | ISSN: XXXX | E-ISSN: XXXX

Vol. 1 No. 1 - Juli 2020 hal. 189-194| Available online at https://www.ejournal.warmadewa.ac.id/index.php/juprehum

\title{
PERLINDUNGAN HUKUM BAGI NOTARIS DALAM MELEGALISASI AKTA DIBAWAH TANGAN YANG MENJADI OBJEK SENGKETA
}

\author{
Ida Ayu Chandra Cintiadewi, I Nyoman Putu Budiartha, Ni Gusti Ketut Sri Astiti \\ Fakultas Hukum Universitas Warmadewa, Denpasar - Bali, Indonesia
}

\begin{abstract}
Abstrak
Notaris sejatinya merupakan pejabat umum yang ditunjuk langs ung oleh negara yang memiliki wewenang membuat akta sebagaimana yang diatur dalam UUJN-P. Selain tugas pokok membuat akta otentik, notaris mempunyai wewenang untuk melegalisasi akta yang dibuat di bawah tangan. Perlindungan hukum bagi Notaris diatur dalam Pasal 66 UUJN-P. Penelitian ini bertujuan untuk memberi pandangan tentang pengaturan hukum kewenangan Notaris dalam pembuatan akta di bawah tangan yang menjadi objek sengketa dan perlindungan hukum bagi Notaris bersangkutan dalam melegalisasi akta tersebut. Menggunakan metode penelitian normative dengan didukung oleh data empiris, hasil penelitian menunjukkan bahwa, pertama, pengaturan kewenangan Notaris dalam membuat akta dibedakan menjadi dua yaitu akta otentik (akta notariil) dan akta di bawah tangan. Pada kekuatan pembuktiannya dalam pengadilan, akta di bawah tangan bisa menjadi alat bukti menurut Pasal $1866 \mathrm{BW}$, tetapi tidak sesempurna akta otentik karena apabila syarat formil dan materiil perjanjian tersebut diakui kebenarannya oleh para pihak, sejak itulah kekuatan akta di bawah tangan menjadi alat bukti yang kuat di pengadilan. Kedua, perlindungan hukum dapat terwujudkan melalui upaya preventif dan represif tetapi yang diatur dalam UUJN-P belum menyeluruh bahkan hanya melindungi permukaannya saja, adanya tenggat waktu mengindikasikan adanya kelemahan untukmelindungi. Dengan dibuatnya regulasibaru atau menambahkan unsurunsuryang jelas mengenai perlindungan hukum dapat memperjelas kedudukan Notaris untuk melindungi dirinya dalam suatu konflik yang berujung pada litigasi yang bertujuan untuk menjaga kehormatan profesi Notaris di masyarakat.
\end{abstract}

Kata Kunci: Akta di Bawah Tangan; Legalisasi; Notari; Objek Sengketa; Perlindungan Hukum

\begin{abstract}
A notary public genuinely serves as a public official appointed directly by the state, of which the authority is to make a deed as regulated in Notary Position Act (in Indonesian called UUJN-P). In addition to the main duty of making an authentic deed, the notary has the authority to legalize the deed made under the hand. Legal protection for Notaries is regulated in Article 66 of UUJN-P. This studyaims to put up a standpoint of the legal regulatory concerning the authority of a Notary in making the deed under the hand which is the object of a dispute and legal protection for the Notary concerned in legalizing the mentioned deed. Using normative research method supported by empirical data, the results of the study show that, firstly, regarding the Notary au thority in making a deed is divided into two, an authentic deed (notarial deed) and a deed under the hand. In the legal power of its evidence in court, a deed made under the hand can be evidence according to Article 1866 BW, but is not as perfect as an authentic deed because when the formal and material conditions of the agreement are recognized by the parties, since then the power of the deed under the hand becomes a strong evidence in the court. Secondly, legal protection can be realized through preventive and repressive efforts, but what is regulated in UUJN-P is not comprehensive yet it only protects the outside, a deadline indicates a weakness to protect. Making new regulations or adding clear elements of legal protection can clarify the position of the Notary to protect themselves in a conflict that results in litigation aimed at maintaining the honour of the Notary profession in society.
\end{abstract}

Keywords: Deed under the Hand; Legalization; Notary; Dispute Object; Legal Protection

\section{PENDAHULUAN}

Seiring dengan perkembangan masyarakat yang dinamis, perjanjian dari masa ke masa juga memiliki perubahan tersendiri. Perjanjian adalah suatu peristiwa antara dua orang untuk melaksanakan suatu hal yang menimbulkan perikatan (Subekti, 2001: 1). Suatu perjanjian mengikatkan dua orang atau lebih secara tidak langsung menyatakan bahwa mereka menyetujui adanya hubungan hukum antara para 
pihak dengan tujuan menjamin pemenuhan prestasinya berdasarkan isi perjanjian. Isi perjanjian tersebut dapat dituangkan dalam bentuk fisik yaitu akta perjanjian yang dapat dipergunakan sebagai bukti apabila sebagai salah satu pihak wanprestasi.

Fungsi pokok dibuatnya akta perjanjian adalah untuk mendapat kepastian hukum yang jelas, menjamin kesepakatan yang disetujui oleh kedua belah pihak dan menghindari konflik yang berujung sengketa di kemudian hari. Akta di bawah tangan ialah akta yang dibuat oleh hanya para pihak, berisi kesepakatan yang sudah disetujui oleh kedua belah pihak yang dibuat secara privat bukan dibuat dan disahkan di hadapan Notaris. Mengenai isi dari akta di bawah tangan Notaris tidak memiliki tanggung jawab sepenuhnya seperti akta otentik, Notaris hanya bertugas melegalisasi dan mencatatkan akta di bawah tangan tersebut (Anand, 2018: 19).

Meskipun Notaris merupakan pejabat umum karena melaksanakan sebagian tugas dan kewajiban pemerintah, Notaris bukanlah seorang pegawainegeri sebagaimana yang diatur dalam peraturan tentang kepegawaian. Notaris diangkat oleh pemerintah, tetapi tidak menerima gaji maupun dana pensiun dari pemerintah penghasilan Notaris sendiri berasal dari honorarium kliennya (Anand, 2018: 35). Notaris berwenang untuk melegalisasi akta di bawahtangan, yang menurut UUJN-P adalahmengesahkan tanda tangan dan menetapkan kepastian tanggal atas akta di bawah tangan dan kemudian mencatatkanya ke dalam Protokol Notaris.

Perlindungan, dalam KBBI (Kamus Besar Bahasa Indonesia) memiliki makna perlindungan atau memberikan tempat berlindung pada sesuatu atau pada perbuatan. Perlindungan berarti memberikan tempat ataupun wadah pada suatu atau perbuatan agar memiliki rasa aman, nyaman dan terjaga (Departemen Pendidikan Nasional, 2008). Notaris dalam menjalankan profesinya tidak memiliki imunitas atau kekebalan terhadap hukum yang berlaku. Meskipun sebagai pejabat umum yang ditunjuk langsung oleh pemerintah, Notaris dapat dituntut apabila melanggar kode etik yang kemudian merugikan para pihak. Tetapi apabila Notaris telah menjalankan amanat sesuai dengan permintaan para pihak, Notaris tidak dapat dipidana apabila mampu membuktikan ia telah mengikuti prosedur yang berlaku.

Terkait Notaris, hubungannya dengan akta di bawah tangan di Indonesia telah banyak muncul dalam kajian-kajian para sarjana dan peneliti (Yusrizal, 2008; Hendra, 2012; Puspa dkk., 2016; dan Dyani, 2017). Namun terkait dengan perlindungan hukum bagi Notaris dalam membuat akta di bawah tangan yang menjadi objek sengketa dan pengaturan hukumnya masih merupakan poin yang perlu disentuh oleh penelitian. Melihat situasi itu, penelitian saat ini hadir untuk mengungkap dua hal yang telah disebutkan terkait dengan Notaris dan akta di bawah tangan yang menjadi obejek sengketa.

Kajian mengungkap jawaban atas dua pertanyaan terkait Notaris (1) Bagaimanakah pengaturan kewenangan Notaris dalam melegalisasi akta di bawah tangan? (2) Bagaimanakah upaya perlindungan hukum bagi Notaris terhadap legalisasi akta di bawah tangan yang menjadi objek sengketa?

\section{METODE PENELITIAN}

Metode penelitian yang digunakan dalam penelitian ini adalah metode hukum normatif, yaitu penelitian yang memanfaatkan berbagai sumber hukum, seperti peraturan perundang-undangan, yurisprudensi, teori-teori hukum maupun penelitian terkait terdahulu. Pendekatan yang digunakan adalah pendekatan perundang-undangan dan pendekatan konsep. Teknik pengumpulan bahan hukum untuk data primer yaitu dengan mendata, merinci dan meringkas yang selanjutnya dianalisis dengan pemahaman peneliti dan diuraikan dalam bentuk deskripsi kepada pembaca, sedangkan untuk data sekunder dihimpun dari artikel-artikel jurnal di bidang hukum, internet, dan juga wawancara kepada pihak terkait yaitu Notaris. Selanjutnya, hasil penelitian diformulasikan secara tepat dan disajikan secara deskriptif dan simpulan-simpulan ditarik.

\section{HASIL DAN PEMBAHASAN}

\section{Pengaturan Wewenang Notaris dalam Melegalisasi Akta di bawah Tangan}

Akta di bawah tangan adalah akta yang dibuat oleh para pihak dan dengan kesepakatan para-para pihak, yang pembuatannya harus berbentuk tulisan berisi tanda tangan para pihak pada bagian akhirnya (Kie, 2007: 516). Dibuatnya akta di bawah tangan untuk menjamin perbuatan hukum yang disetujui kedua belah pihak yang memiliki tujuan progresif, yaitu demi menghindari kemungkinan salah satu pihaknya melakukan wanprestasi di masa yang akan datang. 
Tidak semua perjanjian dapat dibuat dalam bentuk akta di bawah tangan, beberapa jenis perjanjian mewajibkan pembuatan aktanya berbentuk akta otentik sebagai syarat yang telah diatur dalam peraturan perundang-undangan. Mengenai kekuatan pembuktian di pengadilan, akta di bawah tangan kedudukannya berada di bawah akta otentik karena akta otentik keberadaannya sebagai bukti tidak terbantahkan dan menjadi satu-satunya alat bukti sempurna. Berdasarkan Pasal 1875 KUH Perdata meskipun suatu akta yang bersifat di bawah tangan, dalam hal kedudukannya pada pembuktian di pengadilan terbagi menjadi dua, pertama apabila akta di bawah tangan diakui oleh para pihak akta tersebut serta-merta menjadi alat bukti yang sempurna, kedua apabila kebenaran akta di bawah tangan tidak diakui oleh salah satu pihak maka kekuatan akta tersebut menjadi lemah dan selanjutnya dalam pembuktiannya menjadi kekuasaan hakim untuk melanjutkan ataupun mengesampingkan.

Legalisasi adalah akta di bawahtangan yang belum ditandatangani oleh orangnya, setelah isi akta dijelaskan oleh Notaris kepadanya. Dalam hal ini, tanggal dan tanda tangan adalah pasti, karena isi akta dijelaskan oleh Notaris maka penandatangan tidak dapat mengatakan bawah ia tidak mengerti apa yang ditandatangani, penandatangan adalah benar orang yang namanya tertulis dalam keterangan tersebut (Kie, 2007: 520).

Berdasarkan pendapat di atas, legalisasi berarti memastikan kebenaran dalam hal pembuktian bahwa perjanjian di bawah tangan tersebut sebenar- benarnya ditandatangani oleh pihak-pihak yang membuatnya di hadapan Notaris selaku pejabat umum yang berwenang untuk mengesahkan tanda tagan dan menetapkan kepastian tanggal surat di bawah tangan yang kemudian mencatatkannya dalam buku khusus. Kekuatan akta di bawah tangan yang telah dilegalisasi oleh Notaris perihal pembuktiannya di pengadilan, dengan para pihak yang tandatangannya mengakui tanda tangan tersebut, maka isi dan maksud dari akta dianggap sebagai kesepakatan karena pada akta di bawah tangan kebenaran dan keabsahannya terletak pada tandatangan yang dicantumkan para pihak, dengan diakuinya tandatangan dari perjanjian tersebut, kekuatan pembuktian dari akta di bawahtangan yang dilegalisasi menjadi alat bukti yang kuat bagi pengadilan tetapi tetap tidak menjadi bukti yang sempurna karena syarat utama akta otentik adalah dibuat oleh pejabat yang berwenang yaitu Notaris.

Legalisasi adalah pengesahan menurut undang-undang atau hukum (Kamus Besar Bahasa Indonesia, diakses pada 29 Januari 2020). Jadi kultur yang berkembang di masyarakat dalam menginterpretasi legalisasi pada dasarnya sejalan dengan makna sebenarnya, walaupun dalam UUJN$\mathrm{P}$ tidak menyebut secara jelas tentang definisi legaliasi, masyarakat sendiri sudah mengerti dan menggunakan sinonim yang tepat tanpa menghilangkan inti makna dari pengertian sebenarnya.

\section{Perlindungan Hukum bagi Notaris dalam Melegalisasi Akta di bawah Tangan yang Menjadi Objek Sengketa}

Perlindungan menurut Hadjon (1987: 4) dibagi menjadi dua macam, yaitu upaya perlindungan hukum preventif dan upaya perlindungan hukum represif. Upaya perlindungan hukum preventif bertujuan untuk mencegah terjadinya sengketa di kemudian hari sedangkan upaya perlindungan hukum represif bertujuan untuk menyelesaikan perselisihan yang mengakibatkan sengketa. Sengketa yang dimaksud adalah perselisihan yang terjadi antara pihak-pihak dalam perjanjian karena adanya wanprestasi yang dilakukan oleh salah satu pihak dalam perjanjian (Amriani, 2012: 13).

Upaya perlindungan hukum preventif bagi Notaris dalam melegalisasi akta di bawah tangan yang menjadi objek sengketa dapat dilihat dari segi pembuatan aktanya. Dalam menjalankan wewenang undang-undang, Notaris memiliki tugas dan kewajiban yang memiliki prioritas yang berbeda. Walaupun tugas dan wewenang Notaris diatur dalam UUJN Perubahan, pada wewenang yang diatur dalam Pasal 15 ayat 2 huruf a Notaris tidak diwajibkan untuk menjalankannya dalam artian Notaris dapat menolak kewenangan tambahan tersebut apabila tidak sesuai dengan kode etik maupun undangundang yang berlaku. Hal ini tidak berlaku untuk akta otentik karena Notaris adalah pejabat umum yang mempunyai tugas utama membuat akta otentik.

Oleh karena itu pada usaha preventifnya menurut Notaris Denpasar, Nella Hasibuan O'Leary berpendapat untuk akta dibawah tangan yang dilegalisasi pada saat penyusunannya dibantu oleh Notaris ataupun pihak yang memiliki wawasan luas di bidang hukum dengan tujuan agar tidak bertentangan dengan peraturan perundang-undangan yang berlaku dan kedepannya tidak merugikan semua pihak yang terlibat (Wawancara dengan Notaris Kota Denpasar Nella Hasibuan O'Leary tanggal 13 Januari 2020). 
Dalam aspek eksternalnya, peran Kemenkumham sebagai instansi pemerintahan terkait perlu ditingkatkan dalam lingkup pembentukan dan pengawasan di bidang kenotariatan, tidak saja dalam Profesi Notaris tetapi juga pembinaan dan pendidikan calon Notaris yang konsisten dan memiliki akhlak yang baik. Pengawasan yang dalam praktiknya dilakukan oleh Majelis Pengawas di tiap-tiap daerah hendaknya memiliki anggota yang berasal dari praktisi hukum dan juga akademisi dengan tujuan agar melihat suatu masalah dari dua sudut pandang yang berbeda dan dapat memberikan pendapat hukum sesuai dengan apa yang dipermasalahkan.

Untuk faktor internalnya, Notaris sebaiknya dalam menjalankan profesinya yang berpedoman pada tugas dan kewajiban yang diatur dalam UUJN Perubahan yang pembuatan aktanya wajib berdasar pada peraturan perundang-undangan dengan tujuan memberikan tindakan pencegahan sengketa di kemudian hari dan juga memberikan perlindungan pada tiap-tiap pihak apabila kelak terjadi wanprestasi.

Upaya perlindungan represif dalam penyelesaian sengketa dapat dibagi menjadi jalur non litigasi dan jalur litigasi. Penyelesaian jalur non litigasi dapat ditempuhdengan cara konsultasi, negosiasi, mediasi, konsiliasi, atau penilaian ahli (Pasal1 angka 10 Undang-Undang Arbitrase dan Penyelesaian Sengketa di luar Pengadilan). Penyelesaian sengketa dengan jalur non litigasi atau di luar pengadilan memiliki keuntungan lebih dibanding penyelesaian sengketa di peradilan, salah satunya seperti proses penyelesaiannya yang lebih cepat, biaya yang lebih sedikit, kemungkinan mencapai kesepakatan yang dianggap tidak merugikan salah satu pihak. Opsi ini menjadi pilihan masyarakat yang tidak ingin sengketanya berujung pada kerugian materiil maupun inmateriil apabila mereka mengambil jalur litigasi. Pada perlindungan represif dalam penyelesaian sengketa akta dibawah tangan yang dilegalisasi menjadi objek sengketa, pengambilan jalur non litigasi menjadi pilihan yang baik untuk para pihak. Untuk pihak yang berprestasi kemungkinan untuk menemukan jalan tengah dan melanjutkan perjanjian sangat mungkin terjadi, dan untuk pihak saksi yaitu Notaris dapat menjaga penilaian dan martabatnya di masyarakat dan mencegah kerugian yang mungkin didapatkan apabila mengambil jalur peradilan.

Penyelesaian sengketa melalui jalur litigasi menghasilkan sanksi hukum yang dipengaruhi jenis pelanggaran yang dilakukan, di antaranya:

1. Sanksi Perdata

Dalam UUJN Perubahan telah dijelaskan hak dan kewajiban Notaris dalam menjalankan kewenangannya, dan apabila dilanggar dalam proses hukumnya dapat dikenakan sanksi berdasarkan jenis dan tingkat pelanggaran, sanksi keperdataan dapat berupa ganti rugi, pengganti biaya sesuai putusan pengadilan dan penggantian bunga.

2. Sanksi Administratif

Menurut Philipus M. Hadjon, sanksi administrasi meliputi: paksaan dari pemerintah, penarikan kembali keputusan atau ketetapan yang menguntungkan, denda administratif juga denda berupa uang paksa oleh pemerintah (Hadjon, 1987: 245) Dampak sanksi administratif bagi Notaris dalam proses litigasi yaitu dapat dikenakan Surat peringatan, pemberhentian sementara ataupun pencabutan Surat Keputusan Menteri oleh Notaris bersangkutan.

3. Sanksi Pidana

Dalam perlindungan hukum bagi Notaris yang akta hasil legalisasinya menjadi objek tuntutan pidana tidak memiliki perlindungan yang kuat. Menurut Notaris Denpasar Nella Hasibuan Leary, UUJN Perubahan tidak cukup melindungi para Notaris, karena pada Pasal 66 ayat 3 tertuang adanya tenggat waktu selama 30 hari bagi Majelis Kehormatan Notaris untuk memberikan jawaban kepada Penyidik apakah boleh dilakukan pemeriksaan kepada Notaris bersangkutan. Tentu saja ini menjadi suatu kelemahan karena apabila tenggat waktu sudah habis penyidik dengan atau tanpa persetujuan Majelis Pengawas berhak untuk melakukan pemeriksaan (Wawancara dengan Notaris Kota Denpasar Nella Hasibuan O’Leary pada tanggal 13 Januari 2020).

Notaris I Nyoman Alit Puspadma juga menyatakan hal yang serupa, yaitu Majelis Kehormatan Notaris Hanya sebagai filter bagi penyidik maupun Notaris sehingga perlindungannya belum menyeluruh terkait permasalahan pidana. Adanya perbedaan sumber hukum yaitu Kitab UndangUndang Hukum Acara Pidana dengan UUJN Perubahan merupakan penghambat yaitu pemeriksaan oleh penyidik yang tunduk pada KUHP dan KUHAP sedangkan Notaris sebagai pejabat umum 
mempunyai hak untuk diam dan menjaga kerahasiaan para pihak karena tugasnya yang merupakan kewenangan langsung dari undang-undang (Wawancara dengan Notaris Kabupaten Badung I Nyoman Alit Puspadma pada tanggal 7 Januari 2020).

Perlindungan hukum represif pada Notaris dalam menyelesaikan suatu sengketa bergantung pada Majelis Pengawas Notaris yang menjadi pelindung yang ditunjuk oleh undang-undang. Tetapi apabila dalam prakteknya Notaris dimungkinkan melakukan pelanggaran kode etik, Ikatan Notaris Indonesia dibantu dengan Majelis Pengawas Notaris akan memberikan surat peringatan sebagai sanksi internal dari himpunan profesi yang menaungi jabatan tersebut.

\section{SIMPULAN DAN SARAN}

\section{Simpulan}

a. Dalam pengaturan kewenangan Notaris dalam membuat akta dibedakan menjadi 2 yaitu akta otentik atau akta notariil dan akta di bawah tangan. Pada kekuatan pembuktiannya dalam pengadilan, akta dibawah tangan bisa menjadi alat bukti menurut Pasal $1866 \mathrm{BW}$, tetapi dalam kekuatannya tidak sesempurna akta otentik karena apabila syarat formil dan materiil perjanjian tersebut diakui kebenarannya oleh para pihak, maka sejak itulah kekuatan dari akta di bawah tangan menjadi alat bukti yang kuat di pengadilan. Tetapi dalam praktiknya di pengadilan, apabila munculnya alat bukti yang berupa akta di bawah tangan yang tidak bermaterai, kekuatannya dalam pembuktian dikesampingkan.

b. Pelindungan hukum bagi Profesi Notaris dalam melegalisasi akta dibawah tangan yang kemudian menjadi objek sengketa dapat dilakukan dengan upaya preventif dan represif. Pada upaya preventifnya saat penyusunannya dibantu oleh Notaris ataupun pihak yang memiliki wawasan luas di bidang hukum dengan tujuan agar tidak bertentangan dengan peraturan perundang-undangan yang berlaku dan kedepannya tidak merugikan semua pihak yang terlibat juga dapat dengan membuat regulasi baru atau menambahkan unsur-unsur yang jelas mengenai perlindungan hukum bagi Notaris dalam bentuk undang-undang. Sedangkan upaya represifnya pada Notaris dalam menyelesaikan suatu sengketa bergantung pada Majelis Pengawas Notaris yang menjadi pelindung yang ditunjuk oleh undang-undang. Tetapi dalam praktiknya Majelis Pengawas hanya memfilter apakah penyidik dapat melakukan pemeriksaan atau tidak pada Notaris yang disangkakan melakukan penyertaan.

\section{Saran}

a. Saran ditujukan kepada masyarakat dan pemerintah, yaitu dengan dibuatkan regulasi baru dalam hal perlindungan hukum bagi profesi Notaris, undang-undang baru ataupun merevisi undangundang sebelumnya dan menambah unsur perlindungan hukum yang tegas sehingga kedepannya tidak menimbulkan multitafsir maupun kekosongan hukum.

b. Saran ditujukan kepada Notaris yaitu dalam penyusunan draft akta di bawah tangan yang akan dilegalisasi, sebaiknya dalam pembuatan tiap-tiap poinnya dibantu oleh Notaris dengan tujuan untuk kedepannya agar tidak bertentangan pada peraturan perundang-undangan yang berlaku dan dalam kekuatan dalam pembuktian sebaiknya ditandatangani di atas materai 6000 agar lebih kukuh.

\section{DAFTAR PUSTAKA}

Amriani, N. (2012). Mediasi Alternatif Penyelesaian Sengketa Perdata di Pengadilan. PT. Raja Grafindo Persada.

Anand, G. (2018). Karakteristik Jabatan Notaris di Indonesia. Prenadamedia Group.

Departemen Pendidikan Nasional. (2008). Kamus Besar Bahasa Indonesia (4th ed.). Gramedia Pustaka Utama.

Dyani, V. A. (2017). Pertanggungjawaban Hukum dan Perlindungan Hukum bagi Notaris dalam Membuat Party Acte. Jurnal Lex Renaissance, 2(1), 162-176. https://doi.org/10.20885/jlr.vol2.iss1.art11

Hadjon, P. M. (1987). Perlindungan Bagi Rakyat Indonesia. PT. Bina Ilmu.

Hendra, R. (2012). Tanggung Jawab Notaris Terhadap Akta Otentik Yang Penghadapnya Mempergunakan Identitas Palsu. Jurnal Ilmu Hukum Riau, 2(02), 188-200.

Kie, T. T. (2007). Studi Notariat dan Serba-Serbi Praktek Notaris. PT. Ichtiar Baru Van Hoeve. 
Puspa, W. T., Harjono, \& Winarno, D. W. (2016). Tanggungjawab Notaris terhadap Kebenaran Akta di Bawah Tangan yang Dilegalisasi oleh Notaris. Jurnal Repertorium, 3(2), 154-163. https://www.neliti.com/publications/213250/tanggungjawab-notaris-terhadap-kebenaran-aktadibawah-tangan-yang-dilegalisasi-o

Subekti, R. (2001). Hukum Perjanjian. PT. Intermasa.

Yusrizal, K. (2008). Tinjauan Hukum terhadap Kekuatan Pembuktian Akta di Bawah Tangan Dihubungkan dengan Kewenangan Notaris dalam Pasal 15 Ayat (2) UU Nomor 30 Tahun 2004 tentang Jabatan Notaris (Issue 2) [Universitas Diponegoro]. https://www.google.com/url? sa=t\&rct=j\&q=\&esrc=s\&source=web\&cd=\&cad=rja\&uact=8\&ved $=2 \mathrm{ahUKEwj}-$

28PYje_qAhXUmeYKHYIQC8wQFjAAegQIARAB\&url=https\%3A\%2F\%2Fcore.ac.uk\%2Fdo wnload\%2Fpdf\%2F11717741.pdf\&usg=AOvVaw1070gV_XZwXJij9niMi7Sa

Undang-Undang No. 30 Tahun 1999 tentang Arbitrase dan Penyelesaian

Sengketa di Luar Pengadilan, Lembaran Negara Republik Indonesia Tahun 1999

Nomor 138, Tambahan Lembaran Negara Tahun 1999 Nomor 3872. 